\title{
UNA PUERTA
}

Pensé que estaba bien

cerrar con mar

lo que había iniciado entre las olas.

Asistir a la puerta que se cierra

como si solo fuera

otra presencia.

Pero no cesa el viento

de remover los nombres y sus sombras,

la antigua reciedumbre de las aguas

que conducen los ciclos de la luna.

Lecho somos de tiempo que no vuelve, sedimento de historias disipadas y esta ciega constancia de las horas.

No hay forma, sólo puertas que son nubes,

una mano que gira en la madeja oscura de los sueños,

un deseo sin rostro:

el no de los espejos, inclinado

sobre el huidizo horizonte de las cosas.

Nada puede cerrarse, todo vuelve y es distinta la hora y es la misma, va labrando mi cara, que es mi olvido; y la nostalgia, sin melancolía, de todo lo que fue y me ha vivido. 